\title{
Free-living and particle-associated prokaryote metabolism in giant kelp forests: Implications for carbon flux in a sub-Antarctic coastal area
}

\author{
Mathilde Schapira*, Christopher D. McQuaid, Pierre W. Froneman
}

Southern Ocean Group, Department of Zoology and Entomology, Rhodes University, PO Box 94, 6140

Grahamstown, South Africa

*: Corresponding author : M. Schapira, email address : $\underline{\text { mathilde.schapira@ifremer.fr }}$

\begin{abstract}
:
Extensive beds of large subtidal kelps are characteristic of many temperate and subpolar coastlines. They provide habitats for a wide range of other species and are sites of high primary production that generate large quantities of water-borne particles and dissolved organic compounds that support distinctive communities of prokaryotes. We measured prokaryotic metabolism along transects from the shore to the outside of three giant kelp forests (Macrocystis pyrifera) located in the shelf waters of the Prince Edward Islands (Southern Ocean). Abundance, heterotrophic production (PHP), respiration rates (R-ETS) and growth efficiencies (PGE) were investigated within the particle-associated (PA) and the free-living $(\mathrm{FL})$ communities. Temperature, salinity and inorganic nutrient concentrations indicated distinct hydrological differences among the kelp forests that were related to different levels of freshwater input through island run-off. In contrast, detritus and particulate organic matter concentrations showed a common pattern, decreasing from the near-shore to offshore at all sampling sites, suggesting the retention of organically enriched water masses inshore of the kelp forests. While FL and PA abundances did not differ significantly along transects, FL and PA-PHP and PGE all varied significantly across the kelp forests, following the same pattern across each forest. PA-PGE was significantly higher than FL-PGE in the near-shore waters and farther offshore, while FL-PGE was higher or equal to PA-PGE inside the kelp. This shift can be interpreted in terms of gradients in both the age and origins of organic material across the kelp forests. Higher PA-PGE implies that a larger fraction of organic carbon on colonized particles is converted into prokaryotic biomass and so becomes available to higher trophic levels inshore and offshore of $M$. pyrifera forests than inside the kelp bed. In contrast, low PA-PGE suggests that a large quantity of carbon passes through the PAcommunity and is mainly respired within the kelp forest. These results suggest the retention of particles within giant kelp forests. In controlling the metabolic activity of PA and FL prokaryotes, this retention will influence overall carbon flux around the archipelago. In particular, the observation of a common pattern across different $M$. pyrifera forests has important implications for the role of this species as an autogenic ecological engineer in coastal environments.
\end{abstract}

Keywords: prokaryotes; free-living; particle-associated; growth efficiency; kelp; sub-Antarctic island 


\section{Introduction}

Giant kelp (Macrocystis pyrifera) forests are among the most productive ecosystems in the world (Mann, 2000). Kelp forests occur along many temperate coasts and scattered islands in the Southern Ocean (Wormersley, 1954; Dayton, 1985), providing habitat, food and refuge for in coastal environments and is an important ecosystem engineer (sensu Dayton, 1985; Jones et

al., 1994). More particularly, kelp forests strongly affect flow, reducing water transport from the shore to the outer edge of the kelp and ultimately alter concentrations in flow-derived substances and particles in nearshore coastal waters (e.g. Gaylord et al., 2007; Rosman et al., 2010). While the potential retention of water masses within giant kelp forests has been widely acknowledged (e.g. Pakhomov et al., 2002; Gaylord et al., 2007; Fram et al., 2008), the consequences of this retention on the structure and functioning of organisms at the base of the marine food web remain unclear.

Heterotrophic prokaryotes are critical components of the carbon cycle and food webs in marine ecosystems (e.g. Azam et al., 1983; Williams, 1998; Simo et al., 2002). In particular, the balance between their biomass production and respiration represents a major carbon-flow pathway in these systems (e.g. Azam and Malfatti, 2007). The availability of organic matter (e.g. del Giorgio and Scarborough, 1995; del Giorgio et al., 1997) and inorganic nutrients (Rivkin and Anderson, 1997) is known to control prokaryote metabolic activity tightly. Consequently, the retention of enriched water masses within $M$. pyrifera forests could profoundly affect carbon utilization by prokaryotes and the food web structure of giant kelp forests as well as carbon flux within forests and exchange between them and nearshore waters. Moreover, a substantial amount of suspended debris/particles may accumulate within kelp forests (e.g. Gaylord et al., 2007). Particles are known to be highly active sites of microbial processes (e.g. Grossart and Ploug, 
2000; Simon et al., 2002) and elevated enzymatic activity on particles has been shown to release

80 organic and inorganic nutrients into the surrounding water, creating hot spots that greatly extend

81 the volume of intense decomposition processes (Cho and Azam, 1988; Grossart and Ploug,

82 2001). Therefore, a significant part of overall microbial activity within $M$. pyrifera forests may

83 take place on or in the vicinity of particles.

84 The Prince Edward Islands comprise Marion and Prince Edward Islands, situated in the Indian

85 sector of the Southern Ocean. The archipelago lies directly in the path of the easterly-flowing

86 Antarctic Circumpolar Current (ACC), giving it a west-east or upstream-downstream axis

87 (Ansorge et al. 1999, Froneman et al. 1999). Like many oceanic islands, the archipelago is seasonally home to up to 5 million breeding pairs of top predators including flying seabirds, penguins and mammals (e.g. Chown and Froneman, 2008). A substantial part of the coastline of the archipelago is occupied by dense Macrocystis pyrifera forests, principally in the more sheltered waters of the eastern coast of the larger Marion Island (Attwood et al., 1991). Although the potential for retention of water masses in M. pyrifera forests in the near-shore zone around Marion Island has previously been observed (Pakhomov et al., 2002), the consequences for food web structure and carbon flux are still unknown. and therefore play a mayor role in carbon cycling and downward flux in nearshore waters. The objectives of this study were to (i) characterize the effect of kelp forests on near-shore water masses, (ii) investigate the variability in free-living (FL) and particle-associated (PA) prokaryote

100 abundances and metabolism across different $M$. pyrifera forests, (iii) characterize the role of 101 particles and retention of water masses by kelp forests on the patterns observed in the prokaryotic 
102

communities, and (iv) explore the potential consequences of these changes for carbon retention and downward flux in the shallow shelf waters of these sub-Antarctic islands.

\section{Materials and methods}

\subsection{Sites and sampling}

The Prince Edward Islands (46 $38^{\circ}$ S-37 $57^{\circ} \mathrm{E}$ ) rise from a depth of $3000 \mathrm{~m}$ and the two islands (Prince Edward and Marion) are ca. 10 nautical miles apart and separated by a shallow plateau approximately $200 \mathrm{~m}$ deep. The archipelago has a hyperoceanic climate (Smith and Steenkamp, 1990) characterized by high precipitation and humidity (e.g. average annual precipitation approximately $1975 \mathrm{~mm}$; le Roux and McGeoch, 2008) so that the near-shore waters of the islands are strongly influenced by freshwater run-off. A substantial part of the coastline of the archipelago is occupied by dense kelp forests; Durvillaea antarctica dominates the infra-littoral fringe, while Macrocystis pyrifera, formerly Macrocystis laevis Hay (see Macaya and Zuccarello, 2010), predominates between the $5 \mathrm{~m}$ and $30 \mathrm{~m}$ isobaths, particularly in the comparatively sheltered waters of the eastern coast of Marion Island (Attwood et al., 1991; Beckley and Branch, 1992).

Sampling was undertaken in Macaroni and Archway Bays (Fig. 1) during voyage 145 of the research vessel S.A. Agulhas in early austral autumn (April/May) 2009, using a small motorized launch (Fig. 1). Macaroni Bay is a relatively large sheltered bay, receiving substantial freshwater input (Fig. 1). Sampling was undertaken at two representative sites in Macaroni Bay: (i) a sheltered site inside the bay (M1) and (ii) a more exposed site located in front of the western cape of the bay (M2) (Fig. 1). In contrast, the smaller Archway Bay receives limited freshwater input and is the site of a large colony of King Penguins (i.e. 1500 breeding adults; Crawford et al., 2009). 
At each site, samples were collected at 3 stations perpendicular to the coast located (i) in the

127 near-shore kelp-free waters (i.e. $<5 \mathrm{~m}$ deep), (ii) inside the kelp forest and (iii) offshore of the

128 forest. These stations are hereafter referred to as 'inshore', 'kelp' and 'offshore', respectively

129 (Fig. 1). Temperature and salinity profiles were collected at each sampling station with an XR-

$130620 \mathrm{CTD}$ (conductivity, temperature, depth meter) from the surface to the bottom or a maximum

131 depth of $50 \mathrm{~m}$. Water samples were taken from the sub-surface $(1 \mathrm{~m})$ using a 5-L Niskin bottle.

133 2.2. Dissolved inorganic nutrients

134 For the determination of dissolved inorganic nutrient concentrations (nitrate + nitrite,

135 ammonium and orthophosphate) $20 \mathrm{~mL}$ water samples were filtered through glass-fibre filters

136 (Whatman GF/F) and immediately frozen $\left(-20^{\circ} \mathrm{C}\right)$. Concentrations were determined in the

137 laboratory with a Lachat Flow Injection auto-analyser, following standard protocols (Grasshoff et 138 al., 1999).

139

2.3. Dissolved organic carbon (DOC) and organic nitrogen (DON)

141 For the determination of DOC concentrations, $8 \mathrm{~mL}$ of seawater was gently filtered through

142 pre-combusted glass-fibre filters (Whatman $\mathrm{GF} / \mathrm{F})$, collected in pre-combusted $\left(450^{\circ} \mathrm{C}\right.$ for 12

143 hours) glass ampoules, acidified with 3-4 drops of $45 \% \mathrm{H}_{3} \mathrm{PO}_{4}$ and stored at $-20^{\circ} \mathrm{C}$ until analysis.

144 DOC analysis was performed using the high temperature combustion method on an elemental Hi-

145 TOC analyser following standard protocols (Clesceri et al., 1998).

146 For DON concentrations, aliquots of $60 \mathrm{~mL}$ from each station were gently filtered through

147 pre-combusted glass-fibre filters (Whatman GF/F) in acid-washed polyethylene bottles and stored 148 at $-20^{\circ} \mathrm{C}$ until analysis. Organic and inorganic dissolved nitrogen were determined 
149 photometrically following Koroleff's method (1969). DON concentrations were obtained by

150 subtracting the sum of inorganic nitrogen species (i.e. ammonium + nitrite + nitrate) from the 151 corresponding total dissolved $\mathrm{N}$ concentrations.

152

2.4. Particulate organic carbon (POC) and organic nitrogen (PON)

154 Samples for POC and PON (1-1.5 litres) were filtered through pre-combusted $\left(450^{\circ} \mathrm{C} ; 12\right.$

155 hours) and pre-weighed glass-fibre filters (Whatman $\mathrm{GF} / \mathrm{F}$ ) and stored at $-20^{\circ} \mathrm{C}$ until analysis. In

156 the laboratory, filters were rinsed with MilliQ water, dried at $60^{\circ} \mathrm{C}$ for $24 \mathrm{~h}$, and re-weighed to

157 determine the mass of Suspended Particular Matter (SPM) on the filter (Hewson et al., 2001).

158 Analyses were performed on a Thermo Finnigan Delta XP Plus mass spectrometer interfaced 159 with a Conflo III device to a thermo Flash EA 1112 Elemental Analyser.

\subsection{Phytoplankton biomass}

162 For chlorophyll $a(\mathrm{Chl} a)$ estimates, triplicate $250 \mathrm{~mL}$ samples were gently filtered through 163 glass-fibre filters (Whatman GF/F) and immediately extracted in $8 \mathrm{ml}$ of $90 \%(\mathrm{v} / \mathrm{v})$ acetone for

$16424 \mathrm{~h}$ at $-20^{\circ} \mathrm{C}$. Chl $a$ concentrations $\left(\mu \mathrm{g} \mathrm{L}{ }^{-1}\right)$ were then determined fluorometrically following 165 Holm-Hansen and Riemann (1978). Phaeopigment concentrations $\left(\mu \mathrm{g} \mathrm{L}^{-1}\right)$ were determined after 166 acidification with $1.2 \mathrm{M} \mathrm{HCl}$.

\subsection{Prokaryotic abundance}

169 For the identification and enumeration of prokaryotes, triplicate $1 \mathrm{~mL}$ samples were collected, 170 fixed with $0.5 \%$ (final concentration) glutaraldehyde in the dark at $4^{\circ} \mathrm{C}$ for 15 minutes, quick 171 frozen in liquid nitrogen and then stored at $-80^{\circ} \mathrm{C}$ until analysis (Brussaard, 2004). Prokaryotes 172 were counted after staining with SYBR Green I solution (1:5000 dilution) using a Beckman 
173 Coulter FC500 flow cytometer, following standard protocols (Brussaard, 2004). Fluorescent

174 beads, $1 \mu \mathrm{m}$ in diameter (FluoSpheres $\left.{ }^{\circledR}\right)$ were added to all samples, as an internal size and 175 concentration standard. Prokaryote populations were identified and quantified using the flow

176 cytometry analysis software WinMDI $2.9\left({ }^{\circ}\right.$ Joseph Trotter).

177 Abundance of particle-associated (PA) prokaryotes was estimated in the size fraction greater 178 than $0.8 \mu \mathrm{m}$. Immediately after collection, triplicate $5 \mathrm{~mL}$ samples were filtered through $0.8 \mu \mathrm{m}$ 179 pore size polycarbonate membranes (Isopore filters, Millipore), fixed in $5 \mathrm{~mL}$ glutaraldehyde $180(2 \%)$ in the dark at $4{ }^{\circ} \mathrm{C}$ for 15 minutes, quick frozen in liquid nitrogen and then stored at $-80^{\circ} \mathrm{C}$ 181 until analysis. After being gently thawed, filters were sonicated (306 $\mu \mathrm{m}$ amplitude, $50 \%$ duty 182 cycle, cooling in water bath) for 2 minutes to disperse prokaryotes from the particles (Velji and 183 Albright, 1993). Attached prokaryotes (i.e. in the fraction $>0.8 \mu \mathrm{m}$ ) were identified and counted by flow cytometry after staining with SYBR Green I solution as described above. Free-living (FL) prokaryote abundance was calculated from the difference between total prokaryote abundance in the unfiltered samples and PA prokaryote abundance estimated from the $0.8 \mu \mathrm{m}$ pore-size filters.

\subsection{Prokaryotic heterotrophic production (PHP)}

190 Total heterotrophic production was estimated from ${ }^{3} \mathrm{H}$-Leucine (Amersham, $139 \mathrm{Ci} \mathrm{mmol}^{-1}$ ) 191 incorporation rates into proteins as described by Kirchman et al. (1985). ${ }^{3}$ H-Leucine 192 incorporation rates were measured by incubating triplicate $40 \mathrm{~mL}$ samples and 2 formaldehyde 193 killed blanks ( $2 \%$ final concentration), with a saturating $20 \mathrm{nM}$ leucine final concentration 194 (hot:cold =1:9) in the dark, at in situ temperatures. After 5 hours, incubations were terminated by 195 adding formaldehyde (2\% final concentration) to the samples. Kinetic experiments conducted 196 during this study showed that leucine incorporation was linear during this time period (data not 
198 (GSWP, Millipore), incubated with $3 \mathrm{ml}$ of 5\% ice-cold trichloroacetic acid (TCA) for 15

199 minutes, rinsed 3 times with $3 \mathrm{ml} \mathrm{TCA}$, dried and stored at $-20^{\circ} \mathrm{C}$ until analysis. After being dried 200 overnight, filters were placed in scintillation vials and dissolved with $1 \mathrm{~mL}$ of ethyl acetate for 30 201 minutes. Scintillation cocktail Ultima Gold XR (10 ml) was added to each vial and after $18 \mathrm{~h}$,

202 samples were analysed using a Beckman 5801 liquid scintillation counter. The mean

203 disintegrations per minute (DPM) of the formaldehyde-killed blanks were subtracted from the

204 mean DPM of the respective samples and the resulting DPM converted into leucine incorporation

205 rates. Prokaryotic carbon biomass production was estimated using the conversion factor of $3.1 \mathrm{~kg}$

$206 \mathrm{C} \mathrm{mol}^{-1} \mathrm{Leu}($ Kirchman, 1993).

207 Two sets of samples were incubated at each station: the first set was treated as described to 208 estimate total heterotrophic production and the second set ( 3 replicates and 2 formalin-killed

209 blanks) was filtered through $0.8 \mu \mathrm{m}$ filters after incubation to estimate the heterotrophic

210 production by FL prokaryotes (i.e. fraction $<0.8 \mu \mathrm{m}$ ). As TCA passes through 0.8 -pore size filters

211 during protein extraction (Mével et al., 2008), it was not possible to estimate the production in

212 the $>0.8 \mu \mathrm{m}$ fraction directly, and the heterotrophic production by PA prokaryotes was calculated

213 from the difference between total heterotrophic production and production by FL prokaryotes.

\subsection{Respiratory activity of the electron transport system (R-ETS)}

216 The respiratory activity of the electron transport system (ETS) was investigated in both the

$217>0.8 \mu \mathrm{m}$ (i.e. particle-associated) and the $<0.8 \mu \mathrm{m}$ (i.e. free-living) size fractions. Two-litre

218 samples were filtered through $0.8 \mu \mathrm{m}$ and subsequently through $0.2 \mu \mathrm{m}$ cellulose ester

219 membranes (Millipore, AAWP). Filters were folded into cryovials and immediately stored in

220 liquid nitrogen until analysis in the laboratory. ETS activity was measured using the modification 
221 of the tetrazodium reduction technique described in Arístegui and Montero (1995), with minor

222 modifications to increase the sensitivity of the method following Baltar et al. (2009). Rates of

223 oxygen consumption in carbon units (R-ETS) were calculated using the following equation

224 (Arístegui et al., 2002) and assuming a respiratory quotient of 1.

225

226

$\log R-E T S=0.357+0.750 \log E T S$

\subsection{Data analysis}

229 As the normality assumption was not verified with the Shapiro-Wilk's test (Shapiro and Wilk, 230 1965), non-parametric statistics were used throughout this work (Zar, 1996). Multiple

231 comparisons among stations along transects and among sampling sites, were performed using the 232 Kruskal-Wallis test (KW test hereafter) and subsequently a procedure based on the Tukey test

233 (Zar, 1996) was used to identify different groups of measurements. Comparisons between 234 particle-associated and free-living parameters were conducted using the Wilcoxon-Mann235 Whitney $U$-test ( $U$-test hereafter; Zar, 1996).

\section{Results}

\subsection{Environmental parameters}

239 Temperature and salinity profiles recorded at Archway Bay and M1, exhibited very similar 240 patterns, with temperature slightly decreasing from $5.62^{\circ} \mathrm{C}$ inshore to $5.58^{\circ} \mathrm{C}$ outside the kelp 241 forest and salinity remaining relatively constant along the transect, ranging between 33.70 and 24233.90 (Fig. 2). In contrast, at M2, surface temperature and salinity ranged from $5.47^{\circ} \mathrm{C}$ and $2435.60^{\circ} \mathrm{C}$ and from 33.30 to 33.90 respectively along the transect. Salinity increased from the shore 244 to offshore of the kelp forest and from the surface to the deeper layers (Fig. 2). 
Highest inorganic nutrient concentrations were recorded at M2 (Table 1). At Archway Bay, 246 nitrogen and phosphate concentrations followed a similar pattern along the transect, increasing 247 from the inshore to offshore waters (Table 1). At M1 and M2, the kelp forest was characterized 248 by high $\left[\mathrm{NH}_{4}^{+}\right]$(i.e. $\left.>30 \mu \mathrm{mol} \mathrm{L}{ }^{-1}\right)$ and low $\left[N O_{3}^{-}+N O_{2}^{-}\right]$concentrations (i.e. $<13.0 \mu \mathrm{mol} \mathrm{L}{ }^{-1}$ )

249 (Table 1). A pattern of decreasing phosphate concentrations was observed at M1 with values 250 ranging from $5.3 \mu \mathrm{mol} \mathrm{L}{ }^{-1}$ inshore to $2.0 \mu \mathrm{mol} \mathrm{L}{ }^{-1}$ outside the kelp, whereas at $\mathrm{M} 2$ the lowest 251 concentrations (i.e. $10.7 \mu \mathrm{mol} \mathrm{L}{ }^{-1}$ ) were recorded within the kelp forest (Table 1).

At Archway Bay and M1, DOC concentrations decreased from the shore to the outside of the 253 kelp forest and varied from 82.1 to $72.5 \mu \mathrm{mol} \mathrm{L}^{-1}$ and from 78.3 to $75.8 \mu \mathrm{mol} \mathrm{L}{ }^{-1}$, respectively 254 (Table 1). In contrast, at M2, an increasing gradient was observed with values ranging from 75.0 255 inshore to $81.3 \mu \mathrm{mol} \mathrm{L}-1$ offshore (Table 1). DON concentrations ranged between 2.9 and 7.1 $256 \mu \mathrm{mol} \mathrm{L}{ }^{-1}$ and followed a similar decreasing pattern from the shore to outside the kelp forest at the 2573 sampling sites (Table 1). At Archway Bay and M2, the C: N molar ratio of DOM varied from $258 \quad 12.8$ to 25.4 and from 15.0 to 28.4 respectively along transects. The ratios decreased from the 259 shore to offshore of the forest (Table 1). At M1, C: N molar ratios were low with values 260 remaining below 11.8 along the transect (Table 1).

261 The highest SPM concentrations $\left(32.0 \mu \mathrm{g} \mathrm{L}^{-1}\right)$ were observed at M2, in the inshore waters 262 (Table 1). At the 3 sampling sites, SPM and PON concentrations exhibited a similar pattern along 263 transects, decreasing from the shore to outside the kelp forest (Table 1). At M1 and M2, highest 264 POC concentrations were observed inshore, at $14.1 \mu \mathrm{mol} \mathrm{L} \mathrm{L}^{-1}$ and $23.8 \mu \mathrm{mol} \mathrm{L}{ }^{-1}$, respectively 265 (Table 1). In contrast, at Archway Bay the highest POC concentrations $(14.0 \mu \mathrm{mol} \mathrm{L}-1)$ were 266 recorded within the kelp forest (Table 1). At M1 and M2, the C: N molar ratio of POM varied 267 respectively from 9.4 to 7.8 and from 14.8 to 10.4 , and decreased from inshore to offshore waters 
268 (Table 1). In contrast, at Archway Bay the C: N molar ratio increased from the shore to outside 269 the kelp forest with values ranging from 5.1 to 11.6 (Table 1).

270 Total Chl $a$ concentrations were consistently lower than $0.3 \mu \mathrm{g} \mathrm{L}^{-1}$ over the 3 studied kelp

271 forests (Fig. 3). At Archway Bay and M1, mean Chl $a$ concentrations were significantly $(\mathrm{p}<$ 2720.05 ) higher offshore than inshore. At M2, total Chl $a$ concentrations ranged between 0.11 and $2730.13 \mu \mathrm{g} \mathrm{L}^{-1}$ and did not exhibit any significant spatial patterns ( $p>0.05 ;$ Fig. 3 ). The relative 274 contributions of phaeopigments to total Chl $a$ biomass exhibited similar patterns along all three 275 transects (Fig. 3), decreasing significantly from 31.5\%-68.6\% in the near-shore kelp-free waters 276 to $10.2 \%-21.8 \%$ offshore of the $M$. pyrifera forest $(\mathrm{p}<0.05$; Fig. 3$)$.

\subsection{Prokaryote abundances}

279 Free-living (FL) prokaryotes were significantly more abundant than particle-associated (PA) prokaryotes (Mann-Whitney $U$-test, $\mathrm{p}<0.05$ ), contributing between $88.6 \%$ and $99.5 \%$ of the total prokaryotic abundance within the 3 kelp forests (Table 2). PA and FL prokaryote abundances did not differ significantly along transects for any of the 3 sampling sites (KW test, $\mathrm{p}>0.05$ ). PA abundances ranged from $1.53 \times 10^{3}$ to $9.71 \times 10^{3}$ cell $\mathrm{mL}^{-1}$ and did not differ significantly among sampling sites (KW test, $\mathrm{p}>0.05)$. In contrast, at M1, FL prokaryote abundances ranged between $5.50 \times 10^{4}$ to $7.48 \times 10^{4}$ cell $\mathrm{mL}^{-1}$ and were significantly lower than those recorded along transects 286 at M2 and Archway Bay $(\mathrm{p}<0.05)$.

\subsection{Prokaryotic metabolism}

289 Particle-associated PHP (PA-PHP) ranged from 7.2 to $49.1 \mu \mathrm{mol} \mathrm{C} \mathrm{m}^{-3} \mathrm{~d}^{-1}$ and free-living 290 PHP (FL-PHP) from 0.5 to $20.8 \mu \mathrm{mol} \mathrm{C} \mathrm{m}^{-3} \mathrm{~d}^{-1}$ (Table 3). PA-PHP did not differ significantly 
among sampling sites (KW test, $\mathrm{p}>0.05$ ). In contrast, FL-PHP was significantly lower at M1

292 than at M2 inshore of the kelp forests $(p<0.05$; Table 3$)$.

At Archway Bay, PA-PHP was significantly higher inshore $\left(26.6 \mu \mathrm{mol} \mathrm{C} \mathrm{m}^{-3} \mathrm{~d}^{-1}\right)$ than inside

294 the kelp forest $\left(7.2 \mu \mathrm{mol} \mathrm{C} \mathrm{m}^{-3} \mathrm{~d}^{-1}\right)$, whereas FL-PHP did not differ significantly along the

transect (Table 3). At M1, FL-PHP was significantly higher offshore than inshore, at $12.0 \mu \mathrm{mol} \mathrm{C}$

$\mathrm{m}^{-3} \mathrm{~d}^{-1}$ and $0.5 \mu \mathrm{mol} \mathrm{C} \mathrm{m} \mathrm{m}^{-3} \mathrm{~d}^{-1}$ respectively $(\mathrm{p}<0.05)$, whereas PA-PHP did not differ

significantly along the transect (KW test, $\mathrm{p}>0.05)$ (Table 3). At M2, PA-PHP and FL-PHP

ranged from $9.5 \mu \mathrm{mol} \mathrm{C} \mathrm{m}^{-3} \mathrm{~d}^{-1}$ to $20.8 \mu \mathrm{mol} \mathrm{C} \mathrm{m}^{-3} \mathrm{~d}^{-1}$ and between $11.5 \mu \mathrm{mol} \mathrm{C} \mathrm{m} \mathrm{d}^{-1}$ and

$47.2 \mu \mathrm{mol} \mathrm{C} \mathrm{m} \mathrm{d}^{-3}$ respectively, with no significant variation along the transect $(\mathrm{KW}$ test, $\mathrm{p}>$

$0.05)$.

Particle-associated and free-living R-ETS were highly variable, ranging from 1.1 to 106.7 $\mu \mathrm{mol} \mathrm{C} \mathrm{m} \mathrm{d}^{-3}$ and 1.1 to $86.3 \mu \mathrm{mol} \mathrm{m} \mathrm{m}^{-3}$, respectively (Table 3). At M1, particle-associated RETS varied from 1.1 to $81.9 \mu \mathrm{mol} \mathrm{C} \mathrm{m}^{-3} \mathrm{~d}^{-1}$ along the transect, increasing from the shore to outside the kelp (Table 3). At M2, the highest particle-associated R-ETS were observed within

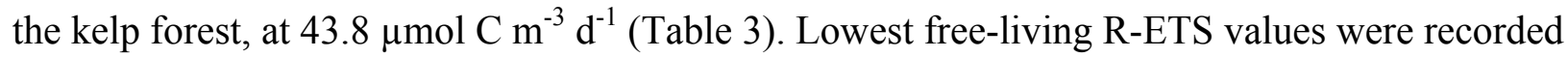

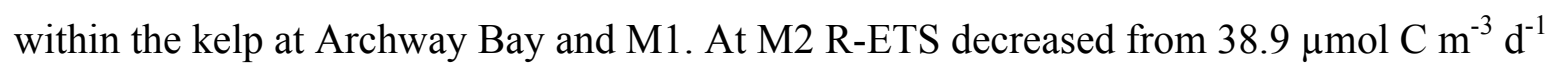

307 inshore to $19.3 \mu \mathrm{mol} \mathrm{C} \mathrm{m}^{-3} \mathrm{~d}^{-1}$ offshore of the kelp forest (Table 3 ).

\subsection{Prokaryotic growth efficiency (PGE)}

310 Prokaryotic growth efficiency (PGE) within the FL and PA communities ranged from 0.01 to 3110.87 and from 0.18 to 0.97 respectively and differed significantly among sampling sites (KW test, $312 \mathrm{p}<0.05$; Fig. 4). Inshore, PA-PGE was significantly higher at M1 than at Archway Bay at 0.97 313 and 0.19 respectively $(\mathrm{p}<0.05)$, whereas FL-PGE did not differ significantly among inshore sites $314(\mathrm{p}>0.05)$. In contrast, FL-PGE measured within the kelp and offshore significantly differed 
315 among sampling sites (KW test $\mathrm{p}<0.5$; Fig. 4). Inside the kelp forest highest FL-PGE was

316 observed at M1whereas highest offshore values were recorded at M2 $(\mathrm{p}<0.05)$.

317 At Archway Bay, PA-PGE ranged from 0.19 to 0.21 (Fig. 4A). FL-PGE was significantly

318 higher within the kelp forest than offshore $(\mathrm{p}<0.05)$ at 0.13 and 0.05 , respectively (Fig. 4A). At

319 M1, PA-PGE varied from 0.97 to 0.21 , decreasing significantly $(\mathrm{p}<0.05)$ from the shore to

320 outside the kelp forest (Fig. 4B) and highest FL-PGE (i.e. 0.84) was observed within the kelp

321 forest (Fig. 4B). At M2, PA-PGE was significantly higher offshore than inside the kelp (p <

3220.05 ) at 0.82 and 0.18 respectively (Fig. 4C). In contrast, FL-PGE ranged between 0.07 and 0.50

323 did not differ significantly along transect (KW test, $\mathrm{p}>0.05)$.

324 Inshore PA-PGE was significantly higher than FL-PGE at all 3 sampling sites ( $U$-test, $\mathrm{p}<$

325 0.05). No significant difference was observed between FL-PGE and PA-PGE within the kelp

326 forest at M2 ( $U$-test, $p>0.05)$, whereas FL-PGE was significantly higher than PA-PGE in the

327 kelp forest at M1 $(U$-test, $\mathrm{p}<0.05)$. Offshore of the kelp forest, PA-PGE was significantly higher

328 than FL-PGE at Archway Bay and M2 $(U$-test, $\mathrm{p}<0.05)$ whereas no significant difference was

329 observed between the two fractions offshore at M1 (U-test, $\mathrm{p}>0.05)$.

331 4. Discussion

\section{4.1. M. pyrifera kelp forests and near-shore water masses}

333 Temperature and salinity profiles indicated different hydrological conditions at the 3 sampling

334 sites (Fig. 2). Surface water of reduced salinity and temperature extended into the kelp forest at

335 M2, suggesting a significant impact of freshwater run-off from the island during sampling (Fig.

336 2). This is consistent with the high ammonium, phosphate and SPM concentrations observed

337 along the transect (Table 1). High concentrations of reduced nitrogen and phosphate have

338 previously been observed in the shallow shelf waters of the island and have been shown to be 
339 largely derived from the guano, dung, urine and animal remains that are carried off the island to 340 the shelf waters via freshwater run-off (Allanson et al., 1985; Ducombe Rae, 1989). In contrast, 341 temperature and salinity profiles recorded at M1 and Archway did not suggest any significant 342 influence of freshwater run-off (Fig. 1). Moreover, despite the high density of top predators on 343 the shore at Archway Bay, inorganic nutrient and SPM concentrations were lower than in 344 Macaroni Bay (Fig. 1; Table 1). These results confirm the importance of freshwater run-off to 345 inorganic nutrient and SPM inputs in the near shore waters.

346 In addition, the differences observed within Macaroni Bay between M1 and M2 demonstrate 347 the restricted nature of the influence of freshwater input, leading to high spatial variability in 348 nutrient and SPM concentrations along the shore. This could have large implications for 349 prokaryote dynamics in the shallow shelf waters of Marion Island. Furthermore, as nutrient 350 availability and light penetration exert a major control on Macrocystis pyrifera growth (Dayton et 351 al., 1992, 1999), this small scale variability in nutrient and SPM inputs may also influence the 352 density and extent of the kelp itself (e.g. Fram et al., 2008) and ultimately the retention capacities 353 of the kelp forests (Gaylord et al., 2007; Rosman et al., 2010).

354 Because both current and vertical mixing are reduced within kelp forests, M. pyrifera has been 355 shown to potentially limit nutrient fluxes and transport of particles from the shore to the outer 356 edge of the forest (e.g. Pakhomov et al., 2002; Rosman et al., 2010). Changes in water masses 357 properties were observed from the shore to the outer edge of the kelp forest at the three sampling 358 sites (Fig. 2; Table 1). However, these changes were sometime small and spatial patterns across 359 kelp beds were not consistent among sampling sites. We are not able to estimate the residence 360 times or flushing rates of water from our data, but as residence times within kelp beds may be 361 high (Graham et al., 2007; Fram et al., 2008), biological activity of both M. pyrifera and its 
associated fauna is likely to have significantly influenced the patterns of inorganic nutrient and 363 organic matter observed.

364 While phytoplankton biomass did not change consistently through the kelp forests, the 365 contribution of phaeopigments to total phytoplankton biomass decreased significantly from 366 inshore to offshore stations at all three locations (Fig. 3), indicating the retention of detritus by 367 the kelp forests (Pakhomov et al., 2002). This is also seen in the offshore decrease in particular 368 and dissolved organic matter (see Table 1). To our knowledge, our results are the first report of 369 POM and DOM enriched waters in near-shore waters and their potential retention within kelp 370 forests. As organic matter supply influences prokaryote growth strongly (e.g. del Giorgio and 371 Cole, 1998), this could have important implications for prokaryote metabolism in other kelp 372 forests.

373 Total prokaryote abundances varied between $6.2 \times 10^{4}$ to $3.6 \times 10^{5}$ cell ml ${ }^{-1}$ over the study area 374 (Table 1). While these abundances are congruent with those observed elsewhere in the Southern 375 Ocean (Pedrós-Alió et al., 2002; Vaqué et al, 2002; Granéli et al., 2004; Corzo et al., 2005; 376 Ortega-Retuerta et al., 2008; Obernosterer et al., 2008), they are within the lower range of values 377 observed offshore of the archipelago in the same months of April/May 2009 (i.e. $3.3 \times 10^{5} \mathrm{cell}^{-}$ $378{ }^{1}$ to $5.5 \times 10^{5} \mathrm{cell} \mathrm{ml}^{-1}$; Schapira et al., 2012). Free-living and particle-associated prokaryote 379 abundances did not vary along transects, but prokaryotic metabolism was highly variable among 380 sampling sites and across the $M$. pyrifera forests. This suggests strong modifications to carbon utilization by prokaryotes along the shore and from the near-shore kelp-free waters to offshore of M. pyrifera forests. This emphasizes that information on prokaryote abundances alone is not enough to evaluate their ecological and functional role in carbon cycling within the plankton, it is necessary to understand their metabolic state as well. 


\subsection{Variability in prokaryote metabolism along the shore of Marion Island}

No significant differences in PA prokaryote abundances were observed, but FL prokaryotes were significantly less abundant at M1 than at M2 and Archway Bay (Table 2). While the supply of dissolved organic matter (DOM) did not exhibit any significant differences among the three sampling sites, $\mathrm{C}: \mathrm{N}$ ratios at M1 were lower than along transects at M2 and Archway Bay (Table 2). The lower $\mathrm{C}: \mathrm{N}$ ratios were accompanied by significantly lower free-living production rates (Table 3). As organic matter supply and stoichiometry (i.e. C: $\mathrm{N}$ ratios) influence prokaryote growth strongly (e.g. del Giorgio and Cole, 1998), the lower FL abundances observed at M1could be explained by a lower quality of DOM at this site. Moreover, this also suggests that despite similar supplies, the organic matter pool is likely to exhibit different degrees of lability and energetic quality at the different locations along the shore, with significant consequences for prokaryote growth and standing stocks. Other factors such as inorganic nutrient concentrations (e.g. Rivkin and Anderson, 1997) and temperature (e.g. Kirchman and Rich, 1997; Rivkin and Legendre, 2001) are strongly affected by freshwater input, and could also have played a role in establishing the differences observed among the different kelp forests. Since multiple factors may interact to control prokaryote production (Church et al., 2000; Smith and Kemp, 2003;

Obernosterer et al., 2008; Mills et al., 2008; Martínez-García et al., 2010), specific experiments are needed to understand fully the limitation of heterotrophic free-living prokaryote production in these shallow shelf waters.

One of the main features of the spatial dynamics of prokaryotic metabolism was the high variability in FL and PA prokaryote growth efficiencies (PGE) among sampling sites (Fig. 4). The PGE values reported in each of the three sampling zones (i.e. inshore, kelp and offshore) varied greatly among the different kelp forests. Since PGE has been shown to vary along gradients of environmental conditions (e.g. Cotner and Biddanda, 2002; Carlson et al., 2007), this 
410 suggests that FL and PA prokaryotes were subject to more or less favorable conditions inshore,

411 inside the kelp and offshore depending on the intrinsic properties of the kelp forest considered

412 (e.g. freshwater input, nutrient dynamics, size of the forest and perhaps the physiological state of

413 the M. pyrifera itself). Since the allocation of energy in prokaryotes depends on many factors

414 (Carlson et al., 2007), it is difficult to identify a single factor responsible for the high variability

415 in PGE observed among kelp forests. Instead we highlight the great variability of free-living and

416 particle-associated PGE that occurred at these small spatial scales. This suggests that the role of

417 kelp forests in shaping the interactions within the microbial loop is strongly dependent on the 418 water in which it is immersed.

\subsection{Spatial variability in prokaryote metabolism across kelp forests}

421 The contribution of particle-associated prokaryotes to total prokaryote abundances is generally 422 between 5 and 10\% (e.g. Cho and Azam, 1988; Simon et al., 2002; Mével et al., 2008). This is 423 consistent with the low contribution of PA prokaryotes (i.e. $<11 \%)$ to the total abundance 424 observed during this study. While the relative abundances of these two fractions of prokaryotes 425 did not vary significantly along transects, their relative contributions to overall carbon flux did. 426 Inshore of $M$. pyrifera forests, the highest PGE were observed within the particle-associated 427 community (Fig. 4). Since PGE typically increase as conditions become optimal (e.g. Cotner and 428 Biddanda, 2002; Carlson et al., 2007), this suggests that environmental conditions in the near 429 shore waters were more favourable for particle-associated than free-living prokaryotes. The near430 shore kelp-free waters showed high concentrations of detritus (SPM) and particulate organic 431 matter with low $\mathrm{C}: \mathrm{N}$ ratios (Table 1), that are characteristic of freshly produced organic matter 432 (e.g. Ogawa et al., 1999; Carlson et al., 2000). High PGE has previously been reported on freshly 433 colonized particles and related to low respiration and/or high production rates associated with 
434 highly labile organic matter (Grossart and Ploug, 2000; Azam and Long, 2001). The high

435 particle-associated PGE observed in this zone may thus be related to the colonization of freshly

436 introduced particles in the inshore kelp-free area.

437 In contrast, free-living PGE were higher than or similar to particle-associated PGE in the kelp, 438 suggesting that environmental conditions were less favourable for particle-associated or more 439 favourable for free-living prokaryotes inside the kelp forest (Fig. 4). As aggregates and particles 440 are likely to be transported from inshore toward the kelp forest interior (e.g. Gaylord et al., 2007), 441 the metabolic activity of attached prokaryotes might have led to a progressive depletion of labile 442 compounds, resulting in more refractory particles within the kelp and ultimately lower particle443 associated PGE (Fig. 4). Furthermore, enzymatic activities and uptake rates are largely decoupled 444 on aged particles, leading to the release of labile compounds in the surrounding media and 445 resulting in the formation of hot spots or plumes of organic and inorganic nutrients around 446 particles (Cho and Azam, 1988; Grossart and Ploug, 2001). Free-living prokaryotes may have 447 clustered in this chemosphere, exploiting the locally high levels of organic and inorganic 448 nutrients (Cho and Azam, 1988; Azam and Malfatti, 2007), leading to high growth efficiencies. 449 However, organic matter is likely to originate from different sources (i.e. terrestrial run-off, kelp450 derived material and phytoplankton) and therefore to have different degrees of lability and 451 energetic quality in the different regions of the forest. In particular, phytoplankton may have 452 contributed to a larger fraction of the DOM and POM pool offshore of the forest where 453 phytoplankton biomass was high (Fig. 3). Changes in organic matter lability and/or the 454 colonization of new particles produced offshore of $M$. pyrifera forest could favour particle455 associated over free-living prokaryotes, leading to higher PGE within the particle-associated 456 community offshore (Fig. 4). 
The allocation of energy in prokaryotes depends on many other factors, making it difficult to 458 identify a single factor controlling the variability in PGE (Carlson et al., 2007). Abiotic factors 459 such as solar radiation (particularly UV-B) and osmotic shock can contribute to an increase in 460 cell respiration (Koch, 1997) and may have played a role particularly in the shallow near-shore 461 kelp-free waters. In addition, viral infection has been demonstrated to increase cell respiration 462 rates in prokaryotes (Bonilla-Findji et al., 2008) and may have been important. Nevertheless, 463 shifts in the predominance of different fractions of the prokaryotic community can be interpreted 464 in terms of gradients in both the age and origins of organic material across the kelp forests. 4.4. Kelp forests, turbulence and prokaryote dynamics

467 One of the main characteristic of $M$. pyrifera is that it significantly alters the local flow 468 environment (e.g. Gaylord et al., 2007; Rosman et al., 2010). Depth averaged currents in kelp 469 forests can be reduced by a factor of 1.5 to 5 relative to nearby kelp-free areas (Jackson, 1998; 470 Gaylord et al., 2007; Rosman et al., 2007). Consequently, colonized particles within forest are 471 likely to be subject to less turbulent conditions than inshore or offshore. As the fluid flow around 472 aggregates plays a critical role in the chemical micro-environment and growth conditions of 473 particle-associated prokaryotes (e.g. Ploug et al., 1997; Ploug, 2001; Simon et al., 2002), 474 modification of turbulence conditions within the kelp forest is likely to influence prokaryotic 475 metabolism. In addition, turbulence intensity at small scales can control nutrient patchiness, with 476 significantly more heterogeneous/patchy distributions under low turbulence conditions (Seuront 477 et al., 2002; Seuront, 2008). At scales relevant to prokaryotes, changes in turbulent conditions 478 across kelp forests may have important consequences to the micro-environment experienced by 479 free-living and particle-associated prokaryotes and may therefore influence their relative 480 contribution to carbon flux. 


\subsection{Implications for carbon flux and food web structure across kelp forests}

483 Regardless of which combination of factors produced the observed pattern, the variability in 484 the growth efficiency of prokaryotes across kelp forests could have significant implications for 485 the fate of organic carbon in these nearshore waters. The significance of higher growth efficiency 486 within the particle-attached community inshore and offshore of $M$. pyrifera forests, is that a 487 larger fraction of organic carbon was converted into prokaryotic biomass and was therefore 488 available to higher trophic levels on colonized particles. Since particle-attached prokaryotes are 489 less susceptible to grazing than their free-living counterparts (Jürgens and Güde 1994; Pernthaler 490 2005), this difference could have significant consequences for food web structure and 491 biogeochemical cycling in the inshore kelp-free area and offshore of the kelp forests.

492 In contrast, particles-associated PGE was lower or equal to the free-living PGE inside the kelp 493 forest. The significance of low particle-associated PGE is that a large quantity of carbon passes 494 through the prokaryote community and is mainly respired inside the kelp forest, so that it is not 495 available to higher trophic levels (Legendre and Rassoulzadegan 1995). Intense remineralisation 496 processes on particles and within their surrounding micro-environment, has important 497 implications for vertical carbon flux within the kelp forest. These findings provide new insights 498 into the role of $M$. pyrifera forests as a bioengineer species in coastal ecosystems.

\section{Conclusion}

$501 \quad$ Metabolic rates of both free-living and particle-associated prokaryotes were highly variable 502 within and among kelp beds, suggesting that the quantity of carbon processed by prokaryotes was 503 strongly influenced by the intrinsic characteristics of the forests (e.g. physiological state of $M$. 504 pyrifera, size of the forest etc.) and by the water in which they were immersed (e.g. freshwater 
505 inputs, sources of organic matter). It is difficult to untangle these various effects, but spatial

506 patterns in prokaryote PGE are interpretable in terms of the age and sources of organic material

507 in the water. Importantly, the variability in prokaryotic growth efficiency has implications for

508 carbon flux within kelp forests.

\section{Acknowledgements}

The authors gratefully acknowledge officers and crew of the research and supply vessel S.A. Agulhas for their assistance at sea and the South African Department of Environmental Affairs and Tourism for providing funds and facilities for this study. Thanks also to E.L. Allan, C.F. McQuaid and R. Young who assisted for the data collection in the kelp forests. Dr. M. Van de Venter from the Department of

Biochemistry and Microbiology in Nelson Mandela Metropolitan University (NMMU) is acknowledged for providing technical support during the flow cytometry work. L. Seuront is acknowledged for his critical reading and helpful comments of an earlier version of the manuscript. Funding was provided by the South African National Antarctic Program (SANAP) and Rhodes University. This work is based upon research supported by the South African Research Chairs Initiative of the Department of Science and Technology and the National Research Foundation.

\section{References}

523 Allanson, B.R., Boden, B.P., Paker, L., Duncombe Rae, C. 1985. A contribution to the oceanology of the Prince Edward Islands. In: Siegfied, W.R., Condy, P.R., Laws, R.M. (eds) Antarctic nutrient cycles and food webs. Springer, Berlin, pp. 38-45.

Ansorge, I.J., Froneman, P.W., Pakhomov, E.A., Lutjeharms, J.R.E., Perissinotto, R., Ballegooyen, R.C. van (1999) Physical-biological coupling in the waters surrounding the Prince Edward Islands (Southern Ocean). Polar Biology 21, 135-145. 
Arístegui, J., Montero, M.F., 1995. The relationship between community respiration and ETS activity in the ocean. Journal of Plankton Research 17, 1563-1571.

Arístegui, J., Denis, M., Almunia, J., Montero, M.F. 2002. Water-column remineralization in the Indian sector of the Southern Ocean during early spring. Deep Sea Research II 49, $1707-$ 1720.

Attwood, C.G., Lucas, M.I., Porbyn, T.A., McQuaid, C.D., Fielding, P.S. 1991. Production and standing stocks of the kelp Macrocystis laevis Hay at the prince Edward Islands, subAntarctic. Polar Biology 11, 129-133.

Azam, F., Fenchel, T., Field, J.G., Gray, J.S., Meyer-Reil, L.A., Thingstad, F. 1983. The ecological role of water-column microbes in the sea. Marine Ecology Progress Series 10, $257-263$.

Azam, F., Long, R.A. 2001. Sea snow microcosms. Nature 414, 495-498.

Azam, F., Malfatti, F. 2007. Microbial structuring of marine ecosystems. Nature Review of Microbiology 5, 782-791.

Baltar, F., Arístegui, J., Gasol, J.M., Sintes, E., Herndl, J. 2009. Evidence of prokaryotic metabolism on suspended particulate organic matter in the dark waters of the subtropical North Atlantic. Limnology and Oceanography 54, 182-193.

Beckley, L.E., Branch, G.M. 1992. A quantitative scuba diving survey of the sub-littoral macrobenthos at subantarctic Marion Island. Polar Biology 11, 553-563.

Bonilla-Findji, O., Malits, A., Lefèvre, D., Rochelle-Newall, E., Lemée, R., Weinbauer, M.G., Gattuso, J.P. 2008. Viral effects on bacterial respiration, production and growth efficiency: Consistent trends in the Southern Ocean and the Mediterranean Sea. Deep Sea Research II $55,790-800$. 
Brussaard, C.P.D. 2004. Optimization of procedures for counting viruses by flow cytometry. Applied and Environmental Microbiology 70, 1506-1513. Cho, B.C., Azam, F. 1988. Major role of bacteria in biogeochemical fluxes in the ocean interior. Nature 332, 441-443.

Carlson, C. A., Hansell D. A., Peltzer E. T., Smith,W. O. Jr. 2000. Stocks and dynamics of dissolved and particulate organic matter in the southern Ross Sea, Antarctica. Deep Sea Research II 47, 3201-3225.

Carlson, C.A., del Giorgio, P.A., Herndl, G.J. 2007. Microbes and the dissipation of energy and respiration: from cells to ecosystems. Oceanography 20, 89-100.

Cho, B.C., Azam, F. 1988. Major role of bacteria in biogeochemical fluxes in the ocean interior. Nature 332, 441-443.

Chown, S.L., Froneman, P.W. 2008. The Prince Edward Islands in a global context. In: Chown, S.L. and Froneman, P.W. (eds.). The Prince Edward Islands: Land-sea interactions in a changing ecosystem. Sun Press, African Sun Media (Pty) Ltd., Stellenbosch, South Africa, pp $1-9$.

Church, M., Hutchins, D.A., Ducklow, H.W. 2000. Limitation of bacterial growth by dissolved organic matter and iron in the Southern Ocean. Applied and Environmental Microbiology 66, $455-466$.

Clesceri, L.S., Greenberg, A.E., Eaton, A.D. 1998. Total organic carbon. In: American Public Health Association (ed), Standards methods for the examination of water and wastewater. Washington DC, Chapter 5, pp. 18-25.

Corzo, A., Rodríguez-Gálvez, S., Lubián, L., Sobrino, C., Sangrá, P., Martínez, A. 2005. Antarctic marine bacterioplankton sub-populations discriminated by their apparent content of nucleic acids differ in their response to ecological factors. Polar Biology 29, 27-39. 
Cotner, J.B., Biddanda, B.A. 2002. Small player, large role: microbial influence on biogeochemical processes in pelagic aquatic ecosystems. Ecosytems 5, 105-121.

Crawford, R.J.M., Whittington, P.A., Upfold, L., Ryan, P.G., Petersen, S.L., Dyer, B.M., Cooper, J. 2009. Recent trends in numbers of four species of penguins at the Prince Edward Islands. African Journal of Marine Science 31, 419-426.

Dayton, P.K. 1985. Ecology of kelp communities. Annual Review of Ecology and Systems. 16: 215-245.

Dayton, P.K., Tegner, M.J., Parnell, P.A., Edwards, P.B. 1992. Temporal and spatial patterns of disturbance and recovery in a kelp forest community. Ecological Monographs 62, 421-445.

Dayton, P.K., Tegner, M.J., Edwards, P.B., Riser, K.L. 1999. Temporal and spatial scales of kelp demography: the role of oceanic climate. Ecological Monographs 69, 219-250.

del Giorgio, P.A., Scarborough, G. 1995. Increase in the proportion of metabolically active bacteria along gradients of enrichment in freshwater and marine plankton: implications for estimates of bacterial growth and production rates. Journal of Plankton Research 17, 19051924.

del Giorgio, P.A., Cole, J.J., Cimbleris, A. 1997. Respiration rates in bacteria exceed phytoplankton production in unproductive aquatic systems. Nature 385, 148-151.

del Giorgio, P.A., Cole, J.J. 1998. Bacterial growth efficiency in natural aquatic systems. Annual Review of Ecology and Systems 29, 503-541.

Duncombe Rae, C.M. 1989. Data report on the first cruise of the Marion Off-shore Ecological study (MOES-1). South African National Science Progress Report 159, pp. 384.

Foster, M.S., Schiel, D.R. 1985. The ecology of giant kelp forests in California : A community profile. U.S Fish and Wildlife Service Biology Report, 85 (7.2). 
Fram, J.P., Stewart, H.L., Brzezinski, M.A., Gaylord, B., Reed, D.C., Williams, S.L., MacIntyre, S. 2008. Physical pathways and utilization of nitrate supply to the giant kelp, Macrocystis pyrifera. Limnology and Oceanography 53, 1589-1603.

Froneman, P.W., Ansorge, I.J., Pakhomov, E.A., Lutjeharms, J.R.E. 1999. Plankton community structure in the physical environment surrounding the Prince Edward Islands (Southern Ocean). Polar Biology 22, 145-155.

Gaylord, B., Rosman, J.H., Reed, D.C., Koseff, J.R., Fram, J., MacIntyre, S., Arkema, K., McDonald, C., Brzezinski, M.A., Largier, J.L., Monismith, S.G., Raimondi, P.T., Mardian, B. 2007. Spatial patterns of flow and their modification within and around giant kelp forest. Limnology and Oceanography 52, 1838-1852.

Granéli, W., Carlsson, P., Bertilsson, S. 2004. Bacterial abundance, production and organic carbon limitation in the Southern Ocean $\left(39-62^{\circ} \mathrm{S}, 4-14^{\circ} \mathrm{E}\right)$ during the austral summer 1997/1998. Deep Sea Research II 51, 2569-2582.

Grasshoff, K., Kremling, K., Ehrhardt, M. 1999. Methods of seawater analysis. $2^{\text {nd }}$ Edition Wiley-VCH Verlag GmbH, Weinheim, Germany, 577 pp.

Grossart, H.P., Ploug, H. 2000. Bacterial production and growth efficiency: Direct measurements on riverine aggregates. Limnology and Oceanography 45, 436-445.

Grossart, H.P., Ploug, H. 2001. Bacterial motility in the sea and its ecological implications. Aquatic Microbial Ecology 25, 247-258.

Hewson, I., O'Neil, J.M., Fuhrman, J.A., Dennison, W.C. 2001. Virus-like particles distribution and abundances in sediments and overlaying waters along eutrophication gradients in two subtropical estuaries. Limnology and Oceanography 46, 1734-1746.

Holm-Hansen, O., Riemann, B. 1978. Chlorophyll- $a$ determination: improvements in methodology. Oikos 30, 438-447. 
622

623

624

625

626

627

628

629

630

631

632

633

634

635

636

637

638

639

640

641

642

643

644

645

Jones, C.G., Lawton, J.H., Shachak, M. 1994. Organisms as ecosystem engineers. Oikos 69, 373386.

Jürgens, K., Güde, H. 1994. The potential importance of grazing-resistant bacteria in planktonic systems. Marine Ecology Progress Series 112, 169-188.

Kirchman, D.L., K’Nees, E., Hodson, R. 1985. Leucine incorporation and its potential as a measure of protein synthesis by bacteria in natural aquatic systems. Applied and Environmental Microbiology 49, 599-607.

Kirchman, D.L. 1993. Leucine incorporation as a measure of biomass production by heterotrophic bacteria. In: Kemp, P.F., Sherr, B.F., Sherr, E.B., Cole, J.J. (eds.), Handbook of methods in aquatic microbial ecology. CRC Press LLC, Boca Raton, Florida, pp. 509-512.

Kirchman, D.L., Rich, J.H. 1997. Regulation of bacterial growth rates by dissolved organic carbon and temperature in the equatorial Pacific Ocean. Microbial Ecology 33, 11-20.

Koch, A.L. 1997. Microbial physiology and ecology of slow growth. Microbial Molecular Biology Review 61, 92-172.

Koroleff, F. 1969. Determination of Total Nitrogen in Natural Waters by Means of Digestion, International. In: Council for the Exploration of the Sea, Hydrography Committee (ed.), CM. 1969/C, pp. 8-4.

Legendre, L., Rassoulzadegan, F. 1996. Food-web mediated export of biogenic carbon in oceans: hydrodynamic control. Marine Ecology Progress Series 145, 179-193.

le Roux, P.C., McGeoch, M.A. 2008. Changes in climate extremes, variability and signature on sub-Antarctic Marion Island. Climate Change 86, 309-329.

Macaya, E.C., Zuccarello, G.C. 2010. DNA barcoding and genetic divergence in the giant kelp Macrocystis (Laminariales). Journal of Phycology 46, 736-742.

Mann, K.H. 2000. Ecology of coastal waters. Blackwell Science, Maldin, MA. 
Martínez-García, S., Fernández, E., Calvo-Diáz, A., Marañón, E., Morán, X.A.G., Teira, E. 2010. Response of heterotrophic and autotrophic microbial plankton to inorganic and organic inputs along a latitudinal transect in the Atlantic Ocean. Biogeosciences 7, 1701-1713.

McCarthy, J.J., Goldman, J.C. 1979. Nitrogeneous nutrition of marine phytoplankton in nutrient depleted waters. Science 203, 670-672.

Mével, G., Vernet, M., Ghiglione, J.F. 2008. Short-term temporal variations of heterotrophic bacterial abundance and production in the open NW Mediterranean Sea. Biogeosciences Discussion 5, 1899-1932.

Mills, M.M., Moore, C.M., Langlois, R., Achterberg, E., Nachtigall, K., Lochte, K., Geider, R.J., La Roche, J. 2008. Nitrogen and phosphorus co-limitation of bacterial productivity and growth in the oligotrophic subtropical North Atlantic. Limnology and Oceanography 51, 824834.

Obernosterer, I., Christaki, U., Lefèvre, D., Catala, P., Van Wambeke, F., Lebaron, P. 2008. Rapid mineralization of organic carbon produced during a phytoplankton bloom induced by natural iron fertilization in the Southern Ocean. Deep Sea Research II 55, 777-789.

Ogawa, H., Fukuda R., Koike, I. 1999. Vertical distribution of dissolved organic carbon and nitrogen in the Southern Ocean. Deep Sea Research I 46, 1809-1826.

Ortega-Retuerta, E., Reche, I., Pulido-Villena, E., Agustí, S., Duarte, C.M. 2008. Exploring the relationship between active bacterioplankton and phytoplankton in the Southern Ocean. Aquatic Microbial Ecology 52, 99-106.

Pakhomov, E.A., Kaehler, S., McQuaid, C.D. 2002. Zooplankton community structure in the kelp beds of the sub-Antarctic Prince Edward Archipelago: are they a refuge for larval stage? Polar Biology 25, 778-788. 
Pedrós-Alio, C., Vaqué, D., Guixa-Boixereu, N., Gasol, J.M. 2002. Prokaryotic biomass and heterotrophic production in western Antarctic waters during the 1995-1996 Austral summer. Deep Sea Research II 49, 805-825.

Pernthaler, J. 2005. Predation on prokaryotes in the water column and its ecological implications. Nature Review Microbiology 3, 537-546.

Ploug, H., Kühl M., Buchholz-Cleven, B., Jørgensen, B.B. 1997. Anoxic aggregates - an ephemeral phenomenon in the pelagic environment. Aquatic Microbial Ecology 13, 285-294.

Ploug, H. 2001. Small-scale oxygen fluxes and remineralization in sinking aggregates. Limnology and Oceanography 46, 1624-1631.

Rivkin, R.B., Anderson, M.R. 1997 Inorganic nutrient limitation of oceanic bacterioplankton. Limnology and Oceanography 42, 730-740.

Rivkin, R.B., Legendre, L. 2001. Biogenic carbon cycling in the upper ocean: effects of microbial respiration. Science 291, 398-400.

Rosman, J.H., Koseff, J.R., Monismith, S.G., Grover, J. 2007. A field investigation into the effects of a kelp forest (Macrocystis pyrifera) on coastal hydrodynamics and transport. Journal of Geophysical Research 112, C02016, doi:10.1029/2005JC003430.

Rosman, J.H., Monismith, S.G., Denny, M.W., Koseff, J.R. 2010. Currents and turbulence within a kelp forest (Macrocystis pyrifera): insights from a dynamically scaled laboratory model. Limnology and Oceanography 55, 1145-1158.

Schapira, M., McQuaid, C.D., Froneman, P.W. 2012. Metabolism of free-living and particleassociated prokaryotes: Consequences for carbon flux around a Southern Ocean archipelago. Journal of Marine Systems 90, 58-66.

Seuront, L., Gentilhomme, V., Lagadeuc, Y. 2002. Small-scale nutrient patches in tidally mixed coastal waters. Marine Ecology Progress Series 232, 29-44. 
693

Seuront, L. 2008. Microscale complexity in the ocean: turbulence, intermittency and plankton life. Mathematical Modelling of Natural Phenomena 3, 1-41.

Shapiro, S.S., Wilk, M.B. 1965. An analysis of variance test for normality (complete samples). Biometrika 52, 591-611.

Simo, R., Archer, S.D., Pedrós-Alió, C., Gilpin, L., Stelfox-Widdicombe, C.E. 2002. Coupled dynamics of dimethylsulfonio-propionate and dimethylsulfide cycling and the microbial food web in surface water of the North Atlantic. Limnology and Oceanography 47, 53-61.

Simon, M., Grossart, H.P., Schweitzer, B., Ploug, H. 2002. Microbial ecology of organic aggregates in aquatic ecosystems. Aquatic Microbial Ecology 28, 175-211.

Smith, E.M., Kemp, W.M. 2003. Planktonic and bacterial respiration along an estuarine gradient: response to carbon and nutrient enrichment. Aquatic Microbial Ecology 30, 251-261.

Smith, V.R., Steenkamp, M. 1990. Climate change and its ecological implications at a subAntarctic Island. Oecologia 85, 14-24.

Vaqué, D., Guixa-Boixereu, N., Gasol, J.M., Pedrós-Alió, C. 2002. Distribution of microbial biomass and importance of protists in regulating prokaryotic assemblages in three areas close to the Antarctic Peninsula in spring and summer 1995/96. Deep Sea Research 49, 847-867.

Velji, M.I., Albright, L.J. 1993. Improved sample preparation for enumeration of aggregated aquatic substrate bacteria. In: Kemp, P.F., Sherr, B.F., Sherr, E.B., Cole, J.J. (eds.) Handbook of methods in aquatic microbial ecology. CRC Press LLC, Boca Raton, Florida, pp 139-142.

Williams, S.C., Hong, Y., Danavall, D.C.A., Howard-Jones, M.H., Gibson, D., Frischer, M.E., Verity, P.G. 1998. Distinguishing between living and nonliving bacteria: evaluation of the vital stain propidium iodide and the combined use with molecular probes in aquatic samples. Journal of Microbiology Methods 32, 225-236. 
716 Wormersley, H.B.S. The species of Macrocystis with special reference to those on southern

717 Australia coast. University of California Publications in Botany 27, 109-132.

718 Zar, J.H. 1996. Biostatistical analysis. Fourth Edition. Prentice Hall International Editions (eds.),

719 Upper Saddle River, New Jersey, pp. 663. 
721 Table 1. Ammonium $\left[\mathrm{NH}_{4}^{+}\right]$, Nitrite + nitrate $\left[\mathrm{NO}_{2}^{-}+\mathrm{NO}_{3}^{-}\right]$, orthophosphate $\left[\mathrm{PO}_{4}^{3-}\right]$, dissolved

722 organic carbon (DOC), dissolved organic nitrogen (DON), suspended particular matter (SPM),

723 particular organic carbon (POC) and particular organic nitrogen (PON) concentrations $\left(\mu \mathrm{mol} \mathrm{l}^{-1}\right)$,

724 and carbon to nitrogen molar ratios of the dissolved organic matter (C: N DOM) and of the

725 particular organic matter (C: N POM) observed at observed (i) inshore, (ii) within the kelp and

726 (iii) offshore of the kelp forest at the 3 sampling sites: Archway Bay, Macaroni Bay 1 and

727 Macaroni Bay 2. Confidence levels $\left(\mu \mathrm{mol} \mathrm{l}^{-1}\right)$ : ammonium $=0.02$; nitrite + nitrate $=0.01$;

728 orthophosphate $=0.07 ; \mathrm{DOC}=0.2 ; \mathrm{DON}=0.1 ; \mathrm{POC}=0.2 ; \mathrm{PON}=0.2 . \times$ : no data available

730 Table 2. Average ( \pm SE) free-living (FL) and particle-associated (PA) prokaryotes abundances

731 (cell $\mathrm{ml}^{-1}$ ) observed (i) inshore, (ii) within the kelp and (iii) offshore of the kelp forest at the 3

732 sampling sites: Archway Bay, Macaroni Bay 1 and Macaroni Bay 2.

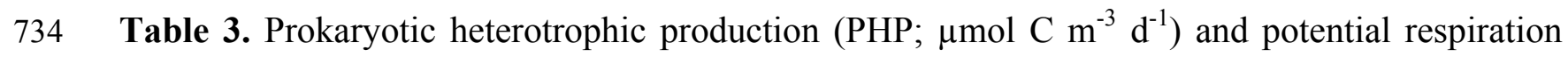

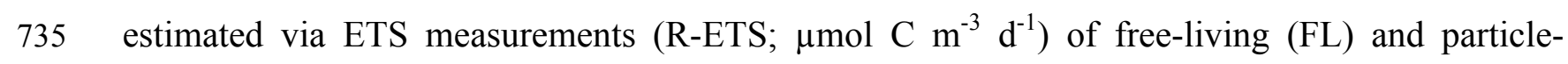
736 associated prokaryotes (PA) observed (i) inshore, (ii) within the kelp and (iii) offshore of the kelp 737 forest at the 3 sampling sites: Archway Bay, Macaroni Bay 1 and Macaroni Bay 2.

\section{$739 \quad$ Figure legends}

740 Fig. 1. Location of sampling sites in the vicinity of Prince Edward Islands. Transects were

741 conducted in 3 kelp forests (Macrocystis pyrifera) located along the east coast of Marion Island:

742 Archway Bay, Macaroni Bay 1 (M1) and Macaroni Bay 2 (M2). Dark grey area between Marion 
743 Island coastline and the $30 \mathrm{~m}$ isobaths shows the kelp forest. At each site, samples were collected

744 at 3 stations (black stars) perpendicular to the coast: in the near-shore kelp-free waters (i.e. depth

$745<5 \mathrm{~m}$ ), within the forest and offshore. SAF: sub-Antarctic Front. APF: Antarctic Polar Front.

746 ACC: easterly-flowing Antarctic Circumpolar Current.

747

748 Fig. 2. Temperature $\left({ }^{\circ} \mathrm{C}\right)$ and salinity profiles recorded along transects at Archway Bay (A and 749 B), Macaroni Bay 1 (C and D) and Macaroni Bay 2 (E and F). Inshore (black marks), inside the 750 kelp forest (white marks) and offshore (grey marks).

751

752 Fig. 3. Average chlorophyll $a$ concentrations $\left([\mathrm{Chl} a] \mu \mathrm{g} \mathrm{L^{-1 }}\right)$ in black bars (A, B and C) and 753 relative concentration of phaeopigments to total chlorophyll $a$ (\% phaeopigments) in grey bars 754 (D, E and F) along transects (inshore, kelp and offshore) at Archway Bay (A and D), Macaroni 755 Bay 1 (M1; B and E) and Macaroni Bay 2 (M2; C and F). The error bars are standard errors. * 756 Significant differences (Tukey test; $\mathrm{p}<0.05$ )

758 Fig. 4. Average prokaryotic growth efficiency PGE of free-living (FL: in grey) and of particle759 associated prokaryotes (PA: in black) along transects (inshore, kelp and offshore) at Archway 760 Bay (A), Macaroni Bay 1 (M1; B) and Macaroni Bay 2 (M2; C). Particle-associated PGE within 761 the kelp at Archway Bay was not calculated as the respirations rates were not available at this 762 station. The error bars are standard errors. * Significant differences between FL-PGE and PA763 PGE (Wilconxon-Mann-Whitney $U$-test; $\mathrm{p}<0.05$ ). 
Table 1. Ammonium $\left[\mathrm{NH}_{4}^{+}\right]$, nitrite + nitrate $\left[\mathrm{NO}_{2}^{-}+\mathrm{NO}_{3}^{-}\right]$, orthophosphate $\left[\mathrm{PO}_{4}^{3-}\right]$, dissolved organic carbo (DOC), dissolved organic nitrogen (DON), suspended particular matter (SPM), particulate organic carbon (POC) an particular organic nitrogen ( $\mathrm{PON}$ ) concentrations ( $\left(\mu \mathrm{mol} \mathrm{I}^{-1}\right.$ ), and carbon to nitrogen molar ratios of the dissolved organi matter (C: NDOM) and of the particular organic matter (C: N POM) observed at observed (i) inshore, (ii) within the kelp an (iii) offshore of the kelp forest at the 3 sampling sites: Archway Bay, Macaroni Bay 1 and Macaroni Bay 2. Confidence level $\left(\right.$ (umol L ${ }^{-1}$ ): ammonium $=0.02$; nitrite + nitrate $=0.01$; orthophosphate $=0.07 ; \mathrm{DOC}=0.2 ; \mathrm{DON}=0.1 ; \mathrm{POC}=0.2 ; \mathrm{PON}=0.2$ > no data available.

\begin{tabular}{|c|c|c|c|c|c|c|c|c|c|}
\hline & \multicolumn{3}{|c|}{ Archway bay } & \multicolumn{3}{|c|}{ Macaroni bay 1} & \multicolumn{3}{|c|}{ Macaroni bay 2} \\
\hline & Inshore & Kelp & Offshore & Inshore & Kelp & Offshore & Inshore & Kelp & Offshore \\
\hline$\left[\mathrm{NH}_{4}^{+}\right]\left(\mu \mathrm{mol} \mathrm{L}{ }^{-1}\right)$ & 5.3 & 8.1 & 9.3 & 11.6 & 33.4 & 11.4 & 22.6 & 31.0 & 27.5 \\
\hline$\left[\mathrm{NO}_{2}^{-}+\mathrm{NO}_{3}^{-}\right]\left(\mu \mathrm{mol} \mathrm{L}{ }^{-1}\right)$ & 13.3 & 13.1 & 14.0 & 15.0 & 12.4 & 13.1 & 17.9 & 13.0 & 17.0 \\
\hline$\left[\mathrm{PO}_{4}^{3-}\right]\left(\mu \mathrm{mol} \mathrm{L}{ }^{-1}\right)$ & 3.0 & 5.6 & 7.1 & 5.3 & 2.9 & 2.0 & 22.0 & 10.7 & 28.0 \\
\hline $\mathrm{DOC}\left(\mathrm{umol} \mathrm{L}^{-1}\right)$ & 82.1 & 77.1 & 72.5 & 78.3 & 78.8 & 75.8 & 75.0 & 77.5 & 81.3 \\
\hline DON $\left(\mu \mathrm{mol} \mathrm{L} \mathrm{L}^{-1}\right)$ & 6.4 & 4.3 & 2.9 & $x$ & 7.1 & 6.4 & 5.0 & 4.3 & 2.9 \\
\hline C: NDOM & 12.8 & 18.0 & 25.4 & $x$ & 11.0 & 11.8 & 15.0 & 18.1 & 28.4 \\
\hline SPM (mg L $\left.{ }^{-1}\right)$ & 16.5 & 16.1 & 15.5 & 30.4 & 16.4 & 15.2 & 32.0 & 30.9 & 30.1 \\
\hline PON $\left(j \mathrm{~mol} \mathrm{~L} \mathrm{~L}^{-1}\right)$ & 1.9 & 1.1 & 1.0 & 1.5 & 0.7 & 1.0 & 1.6 & 0.8 & 0.7 \\
\hline POC ( $\left(\right.$ mol L L $\left.\mathrm{L}^{-1}\right)$ & 9.5 & 14.0 & 11.0 & 14.1 & 6.9 & 7.5 & 23.8 & 7.0 & 7.1 \\
\hline C: N POM & 5.1 & 12.6 & 11.6 & 9.4 & 9.8 & 7.8 & 14.8 & 8.6 & 10.4 \\
\hline
\end{tabular}

Table 2. Average $\left( \pm S E\right.$ ) free-living ( $F L$ ) and particle-associated $(\mathrm{PA})$ prokaryotes abundances (cell $\mathrm{ml}^{-1}$ ) observed (i) inshore, (ii) within the kelp and (iii) offshore of the kelp forest at the 3 sampling sites: Archway Bay, Macaroni Bay 1 and Macaroni Bay 2.

\begin{tabular}{|l|l|l|l} 
Sampling sites & Stations & \multicolumn{2}{l}{ Total abundances (cell $\mathrm{mL}^{-1}$ ) } \\
\cline { 2 - 4 } & & $\mathrm{FL}$ & $\mathrm{PA}$ \\
Archway Bay & Inshore & $2.54 \times 10^{6}\left( \pm 3.50 \times 10^{3}\right)$ & $4.26 \times 10^{3}\left( \pm 1.50 \times 10^{3}\right)$ \\
\hline & Kelp & $3.66 \times 10^{6}\left( \pm 3.34 \times 10^{3}\right)$ & $7.14 \times 10^{3}\left( \pm 3.60 \times 10^{3}\right)$ \\
\hline & Offshore & $3.63 \times 10^{6}\left( \pm 1.11 \times 10^{4}\right)$ & $5.45 \times 10^{3}\left( \pm 1.31 \times 10^{3}\right)$ \\
\hline Macaroni Bay 1 & Inshore & $6.47 \times 10^{4}\left( \pm 4.22 \times 10^{3}\right)$ & $3.87 \times 10^{3}\left( \pm 7.47 \times 10^{2}\right)$ \\
\hline & Kelp & $5.50 \times 10^{4}\left( \pm 2.07 \times 10^{3}\right)$ & $7.08 \times 10^{3}\left( \pm 2.84 \times 10^{3}\right)$ \\
\hline \multirow{2}{*}{ Macaroni Bay 2 } & Inshore & $3.51 \times 10^{6}\left( \pm 1.90 \times 10^{4}\right)$ & $6.71 \times 10^{3}\left( \pm 2.10 \times 10^{3}\right)$ \\
\hline & Kelp & $2.97 \times 10^{6}\left( \pm 8.02 \times 10^{4}\right)$ & $1.53 \times 10^{3}\left( \pm 4.80 \times 10^{2}\right)$ \\
\hline & Offshore & $4.44 \times 10^{6}\left( \pm 3.19 \times 10^{4}\right)$ & $9.71 \times 10^{3}\left( \pm 1.52 \times 10^{3}\right)$ \\
\hline
\end{tabular}

SE: Standard Error. 
Table 3. Prokaryotic heterotrophic production (PHP; $\mu \mathrm{mol} \mathrm{C} \mathrm{m}^{-3} \mathrm{~d}^{-1}$ ) and potential respiration estimated via ETS measurements (R-ETS; $\mu \mathrm{mol} \mathrm{C} \mathrm{m}^{-3} \mathrm{~d}^{-1}$ ) of free-living ( $\mathrm{FL}$ ) and particle-associated prokaryotes ( $\mathrm{PA}$ ) observed (i) inshore, (ii) within the kelp and (iii) offshore of the kelp forest at the 3 sampling sites: Archway Bay, Macaroni Bay 1 and Macaroni Bay 2 .

\begin{tabular}{|c|c|c|c|c|c|}
\hline \multirow[t]{2}{*}{ Sampling sites } & \multirow[t]{2}{*}{ Stations } & \multicolumn{2}{|c|}{ PHP ( 1 mol $\left.\mathrm{C} \mathrm{m}^{-3} \mathrm{~d}^{-1}\right)$ Average $( \pm S E)$} & \multicolumn{2}{|c|}{ R-ETS $\left(\mu \mathrm{mol} C \mathrm{~m}^{-3} \mathrm{~d}^{-1}\right)$} \\
\hline & & $\mathrm{FL}$ & $\mathrm{PA}$ & $\mathrm{FL}$ & $\mathrm{PA}$ \\
\hline \multirow[t]{3}{*}{ Archway Bay } & Inshore & $2.9( \pm 0.2)$ & $26.7( \pm 8.1)$ & 38.9 & 106.7 \\
\hline & Kelp & $2.9( \pm 0.5)$ & $7.2( \pm 1.1)$ & 18.6 & $x$ \\
\hline & Offshore & $4.2( \pm 0.3)$ & $15.9( \pm 0.7)$ & 86.3 & 59.3 \\
\hline \multirow[t]{3}{*}{ Macaroni Bay 1} & Inshore & $0.5( \pm 0.0)$ & $43.1( \pm 5.9)$ & 21.0 & 1.1 \\
\hline & Kelp & $4.0( \pm 1.9)$ & $49.1( \pm 2.9)$ & 1.1 & 74.3 \\
\hline & Offshore & $12.0( \pm 1.5)$ & $22.4( \pm 5.7)$ & 74.3 & 81.9 \\
\hline \multirow[t]{3}{*}{ Macaroni Bay 2} & Inshore & $11.3( \pm 0.0)$ & $11.5( \pm 1.6)$ & 38.9 & 15.2 \\
\hline & Kelp & $9.5( \pm 4.3)$ & $18.1( \pm 11.3)$ & 32.2 & 43.8 \\
\hline & Offshore & $20.8( \pm 5.3)$ & $47.2( \pm 13.0)$ & 19.3 & 8.8 \\
\hline
\end{tabular}

SE: Standard Error $x$ : no data available.

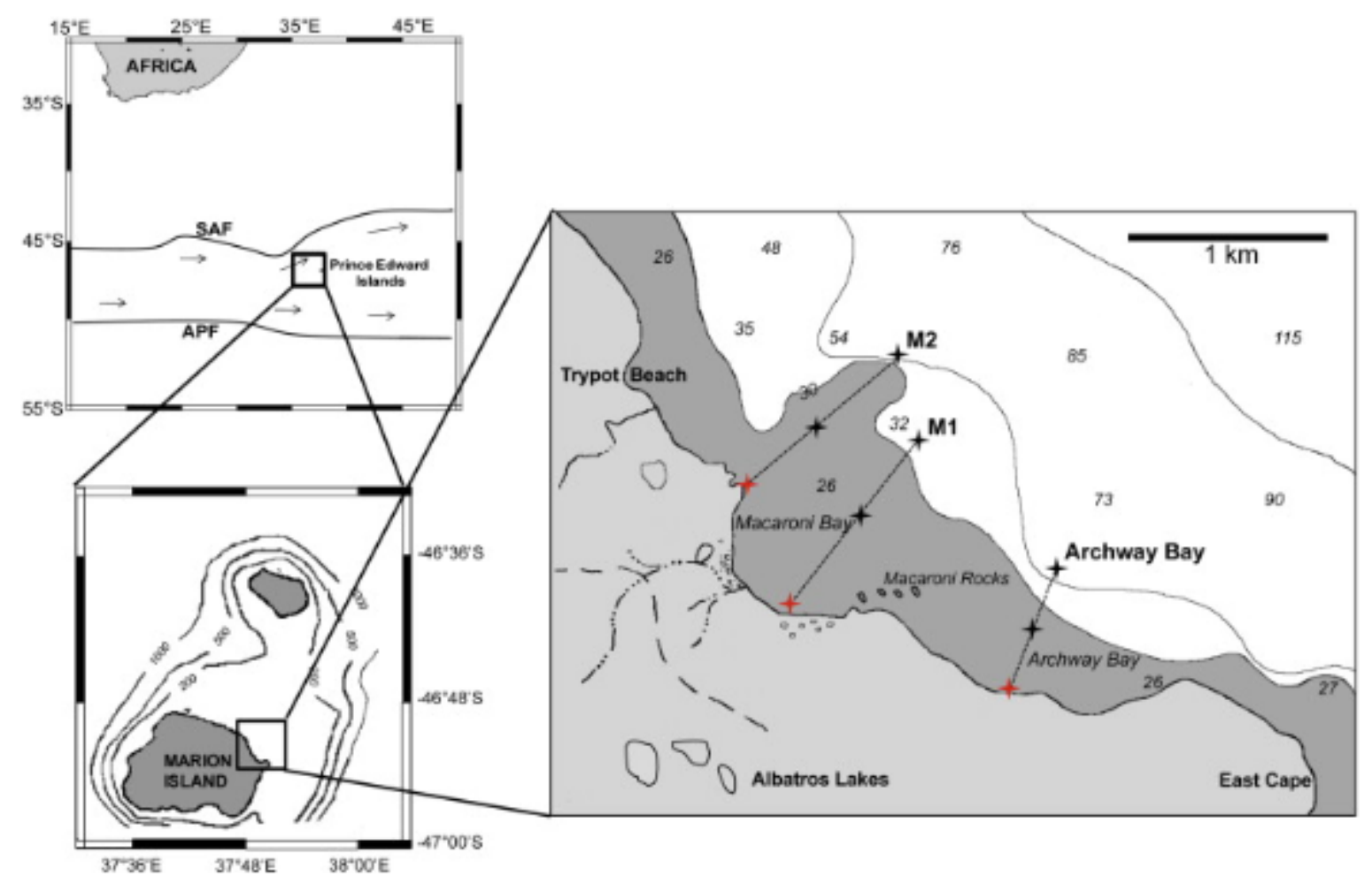

Fig. 1. Location of sampling sites in the vicinity of Prince Edward Islands. Transects were conducted in 3 kelp forests (Macrocystis pyrifers) located along the east coast of Marion Island: Archway Bay, Macaroni Bay 1 (M1) and Macaroni Bay 2 (M2). Dark grey area between Marion Island coastline and the $30 \mathrm{~m}$ isobaths shows the kelp forest. At each site, samples were collected at 3 stations (black stars) perpendicular to the coast: in the near-shore kelp-free waters (i.e. depth $\measuredangle 5 \mathrm{~m}$ ), within the forest and offshore. SAF: sub_Antarctic Front. APF: Antarctic Polar Front. ACC: easterly-flowing Antarctic Circumpolar Current. 
Temperature $\left({ }^{\circ} \mathrm{C}\right)$

Salinity
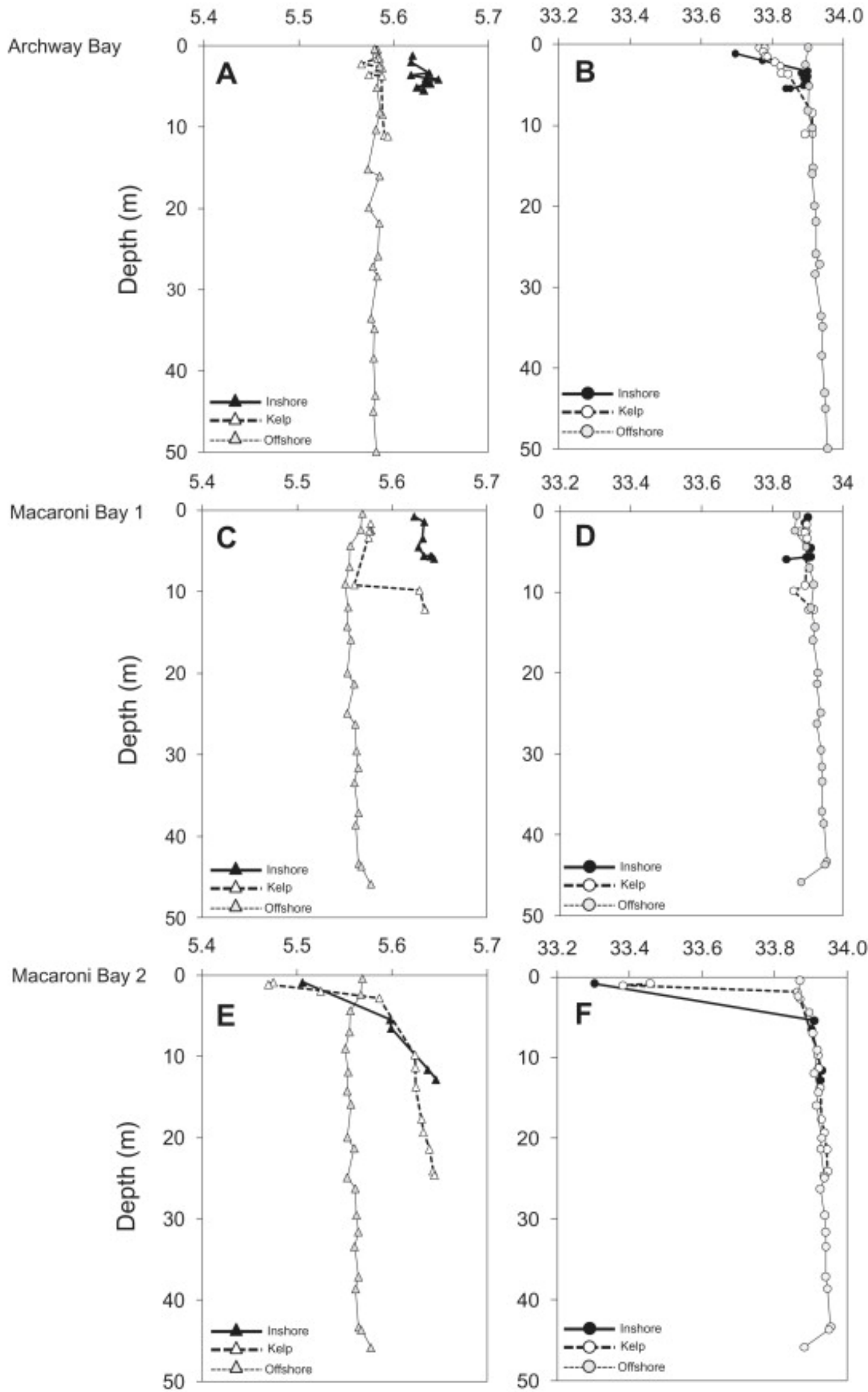

Fig. 2. Temperature $(C)$ ) and salinity profiles recorded along transects at $A r c h w a y$ Bay ( $A$ and $B$ ), Macaroni Bay 1 (C and D) and Macaroni Bay 2 ( $E$ and F). Inshore (black marks), inside the kelp forest (white marks) and offshore (grey marks). 


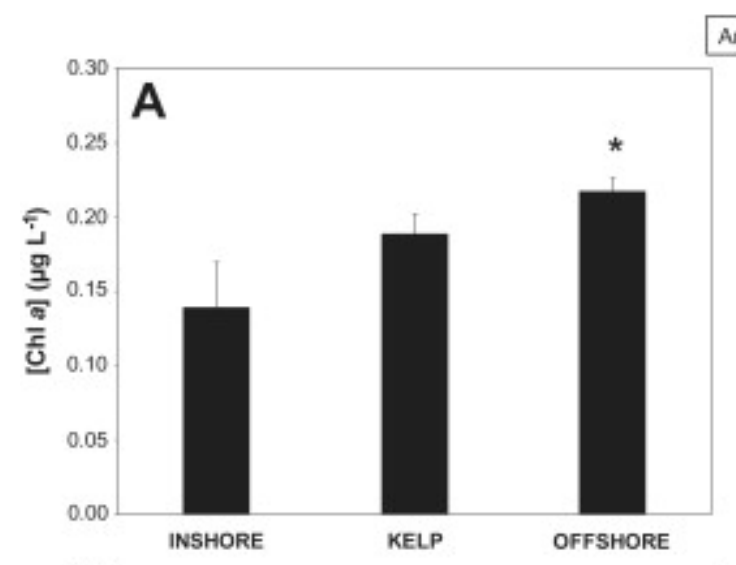

Archway Bay
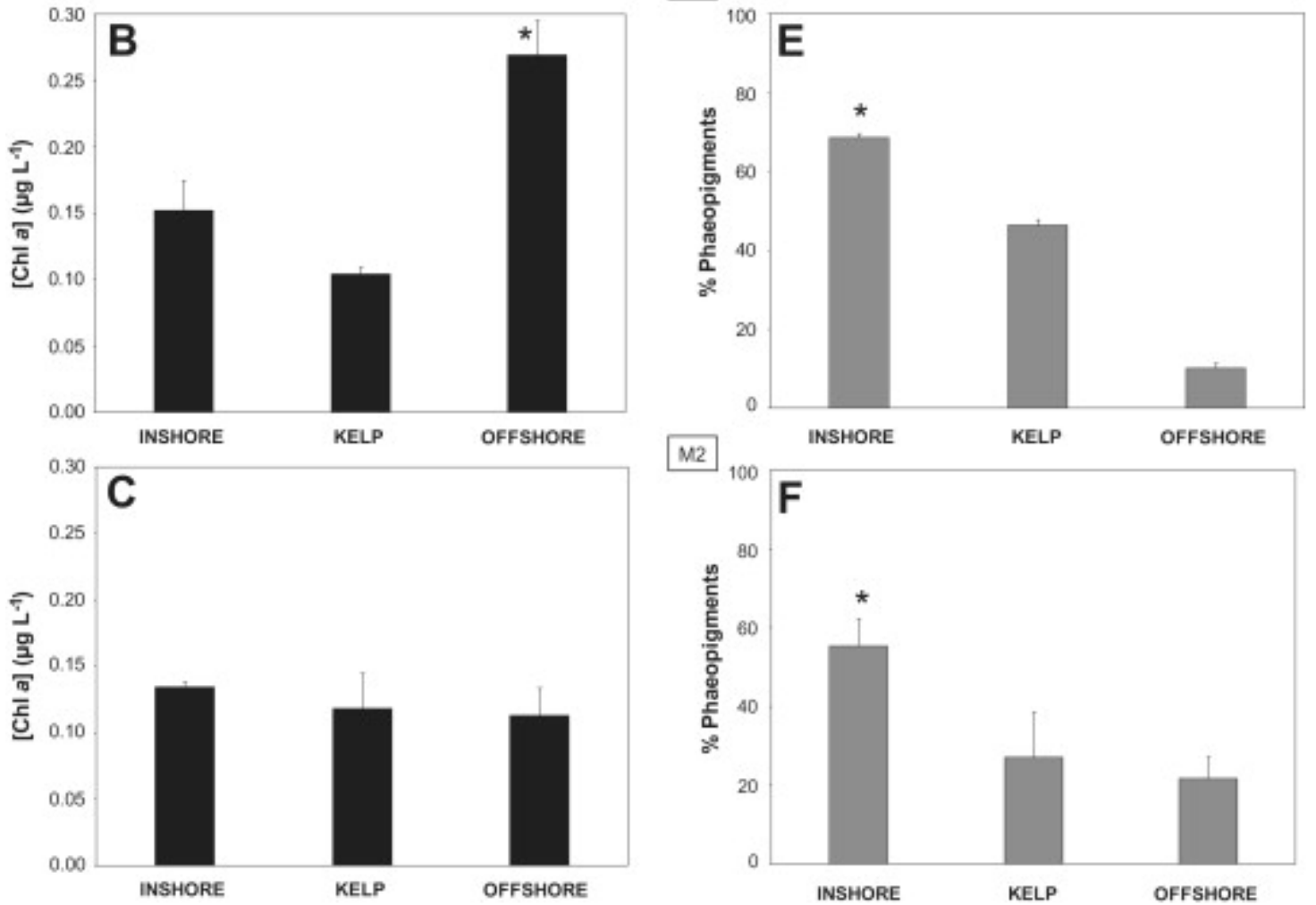

Fig. 3. Average chlorophyll $a$ concentrations $\left([\mathrm{Chl} s] \mu \mathrm{g} \mathrm{L} \mathrm{L}^{-1}\right.$ ) in black bars $(A, B$ and $C$ ) and relative concentration of phaeopigments to total chlorophyll $s$ (\% phaeopigments) in grey bars (D, E and F) along transects (inshore, kelp and offshore) at Archway Bay (A and D), Macaroni Bay 1 (M1; B and E) and Macaroni Bay $2(\mathrm{M} 2 ; \mathrm{C}$ and F). The error bars are standard errors. * Significant differences (Tukey test; $\rho<0.05)$. 

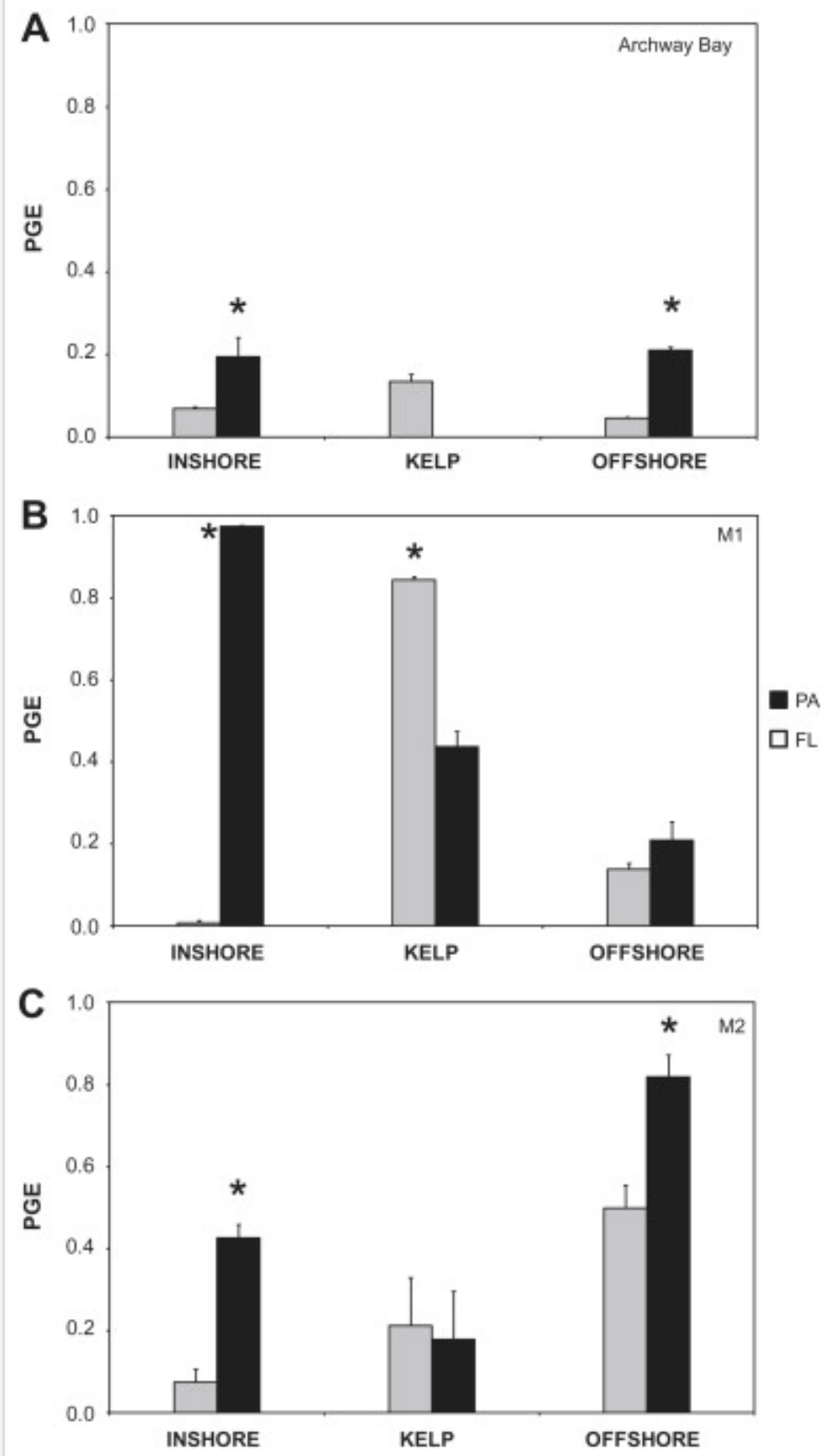

Fig. 4. Average prokaryotic growth efficiency PGE of free-living (FL: in grey) and of particle-associated prokaryotes (PA: in black) along transects (inshore, kelp and offshore) at Archway Bay (A), Macaroni Bay1 (M1; B) and Macaroni Bay 2 (M2; C). Particle-associated PGE within the kelp at Archway Bay was not calculated as the respirations rates were not available at this station. The error bars are standard errors. * Significant differences between FL-PGE and PA-PGE (ứilconxonMann-iuhitney Utest; $\rho<0.05$ ). 